\title{
Yield Improvement in Tomato through Certain Micronutrients in Central Plain Zone (Pb-3) of Punjab, India
}

\author{
Sandeep Kumar, Anamika Verma* and Arwankie Shadap \\ Department of Horticulture, School of Agriculture, Lovely Professional University, \\ Phagwara, Punjab, India \\ *Corresponding author
}

\section{A B S T R A C T}

\section{Keywords \\ Micronutrient, Shivaji Gold, Tomato, Boron, Zinc, Iron, Foliar application, Yield \\ Article Info \\ Accepted: \\ 12 April 2019 \\ Available Online: \\ 10 May 2019}

\begin{abstract}
A field experiment was conducted to evaluate the possible effect of some micro nutrients with different concentration levels as a foliar application on the vegetative growth, quality and yield of F1 hybrid tomato "Shivaji Gold". The experiment was conducted at Lovely Professional University, Jalandhar Punjab India during 2018. The field experiment was laid in a randomized block design with three replications comparing eleven treatments involving different dose of micronutrients i.e. Boron, Iron, Zinc and absolute control to study the yield and quality parameters following of the experiment. The study revealed that the mixture of B + Fe + Zn @0.4\% was found to give highest fruit yield $\left(36.83 \mathrm{tha}^{-1}\right)$ as compared to individual micronutrient. This treatment also enhanced the growth, yield and quality attributes viz. plant height, number of flower per plant, number of compound leaf, weight of fruit, yield per plant, ascorbic acid content and TSS. Therefore, micronutrient application is suitable way to enhance the growth, flowering and marketable yield of tomato crop.
\end{abstract}

\section{Introduction}

Tomato (Solanum lycopersicon Mill.) is the most important crop among the most broadly used vegetable of solanaceae family, originated in South America (Harlan, 1992). It has wide adaptability to various agroclimatic conditions of India (Saravaiya et al., 2014). It is a rich source of Vitamin C, Calcium and Phosphorus along with $\beta$ carotene and lycopene pigments which keeps the blood vessels healthy and avoids scurvy (Ejaz et al, 2011). Tomatoes are majorly exported on a broad scale in USA, Russia and Italy. Andhra Pradesh is the major tomato producing state with $12.94 \%$ of production share, followed by Madhya Pradesh, Karnataka, Telangana and Gujarat with $11.68 \%, \quad 11.05 \%, \quad 7.75 \%$ and $6.82 \%$ respectively (NHB database, 2018).

High dosages of NPK alone are not adequate to expand the yield of vegetables and thus, the requirement for micronutrients administration has been felt (Shivappa et al., 2005). It is clear that all vegetables respond 
constructively to the application of small quantities of micro as well as macro-nutrients (Naz et al., 2012). Tomato yield can be pushed up by the judicious use of recommended dose of major nutrients along with micronutrients (Chand and Prasad, 2017). Abiotic stresses like changes in environmental conditions and nutrition results in physiological disorders ultimately decrease crop yield (Khavari-Nejad et al., 2009). Most of the severe physiological disorders in tomato are due to micronutrient deficiency. Nutritional condition of fruit of tomato also gets poor when fruits are produced under poor diversely affected soil condition. Micronutrients improve the chemical composition of fruits and general condition of plants and are known to act as catalyst in promoting organic reactions taking place in plants (Reddy et al., 2018). Foliar spray of micro nutrients significantly influenced the content of micronutrients in fruits, leaves and soil (Singh et al., 2018). Application of Ca, B and $\mathrm{Zn}$ as a foliar spray can be used alone or in combination to improve growth and fruit production of tomato (Haleema et al., 2018).

Boron (B) is an essential nutrient and its primary function is in plant cell wall structural integrity, cell division, nucleic acid synthesis, and uptake of calcium and transport of carbohydrates (Bose and Tripathi, 1996); flowering and fruit formation (Nonnecke, 1989); seed development (Brown et al., 2002; Dordas et al., 2007); membrane transportation (Brown et al., 2002); synthesis of amino acids and proteins (Stanley et al., 1995). Application of zinc sulphate, stimulate chlorophyll synthesis and fruit quality of tomato (Kalloo, 1985). Iron is required for nitrate and sulphate reduction and is associated with chlorophyll formation and photosynthesis. Leaves require at least 60 $\mathrm{mg} / \mathrm{kg}$ of iron prior to flowering for fruit growth. Applications of iron (e.g. as foliar or through fertigation) can be used to increase early leaf production and crop productivity. Considerable research work has been done on the aspect of foliar application of micronutrient in different crops and the experimental results indicated not only increase in yield up to 20 per cent but also helpful to sustain crop production (Saravaiya et al., 2014; Haleema et al., 2018). Keeping in view, all these points present study was conducted to access the suitable micronutrient dose for tomato yield improvement in central plain zone of Punjab.

\section{Materials and Methods}

The experiment was carried out at the Horticulture farm of Lovely Professional University, Phagwara (Punjab) during 2018 with the aim to analyse foliar effect of micronutrients on growth, yield and quality of tomato (Solanum lycopersicon Mill.) hybrid "Shivaji Gold", from "Golden seeds" private company. Shivaji gold is an early hybrid; determinate type; resistant to Verticillium \& Fusarium wilt. The experimental site is characterized as "Central Plain Zone (PB-3)" of Punjab and located at $31^{\circ} 15^{\prime} \mathrm{N}$ latitude and $75041^{\prime}$ E longitudes at an elevation of $245 \mathrm{~m}$ above mean sea level. The whole experimental area $\left(180 \mathrm{~m}^{2}\right)$ was divided into 33 plots, each with area of $2 \times 1 \mathrm{~m}^{2}$. Sowing was done in February 2018 and transplanting in March 2018.

A total of eleven treatments were subjected to the experimental material for analyzing the increment in yield. In all eleven treatments viz. T1 (Boron@ 0.2\%), T2 (Boron@ 0.4\%), T3 (Boron@0.6\%), T4 (Iron@ 0.2\%), T5 (Iron@0.4\%), T6 (Iron@0.6\%), T7 (Zinc @ 0.2\%), T8 (Zinc@0.4\%), T9 (Zinc 0.6\%), T10 (Boron@ 0.4\% + Iron@ 0.4\% + Zinc @ $0.4 \%$ ) and T11 (Control) were evaluated in a Random Block Design with three replications. Spraying was done with knapsack sprayer and the leaves were wetted thoroughly with fine 
mist. First foliar spray was applied at 30 days after sowing, second and third at 45 and 60 days after sowing respectively.

The important parameters encompassed in the research study were growth parameters viz. plant height $(\mathrm{cm})$, number of compound leaves, days to $50 \%$ flowering, number of cluster per plant, number of flower per plant. Observations on yield and yield attributing traits were no. of fruits per plant, fruit weight $(\mathrm{g})$, yield per plant $(\mathrm{kg})$ and yield per ha $(\mathrm{t})$. Quality parameters included ascorbic acid content and TSS. The data collected from five randomly selected plants for above said parameters were subjected to analysis of variance technique (ANOVA) and least significance difference test was applied to separate different treatment means (Panse and Sukhatme, 1967). Observations on fruit yield were recorded by the numbers and weight of the fruits harvested from each of the treatments. Similarly the fruit yield was worked out on hectare basis and it was expressed in $t / h a$. The fruit yield was calculated and subjected to ANOVA.

\section{Results and Discussion}

\section{Effect of micronutrients on growth attributing characters}

The result showed effect of micronutrients levels on fruit yield ( $\mathrm{t} / \mathrm{ha}$ ) was found significant. The foliar application of Boron, Iron and Zinc significantly increased fruit yield per plant as well as yield per hectare. The highest $(71.93 \mathrm{~cm})$ plant height was recorded in $\mathrm{T}_{10}(\mathrm{~B}+\mathrm{Fe}+\mathrm{Zn} @ 0.4 \%)$ followed by $(61.80 \mathrm{~cm})$ in $\mathrm{T}_{2}$ (B@ @ $\left.0.4 \%\right)$ which are reported to increase the height by 74.79 and 65.56 percent, respectively over $T_{1}$ (Control). The highest (18.93) number of cluster per plant was recorded in $\mathrm{T}_{10}(\mathrm{~B}+\mathrm{Fe}$ $+\mathrm{Zn} @ 0.4 \%)$ followed by (13) in $\mathrm{T}_{9}(\mathrm{Zn}$ $0.6 \%$ ) which increased the number of cluster per plant by 221.21 and 219.23 percent, respectively over $\mathrm{T}_{1}$ (Control). The highest (34.26) number of flowers was reported in $\mathrm{T}_{10}$ followed by (28.73) in $\mathrm{T}_{3}$ (B $0.6 \%$ ), which was found to increase the number of flowers by 305.55 and $272.22 \%$, respectively over $\mathrm{T}_{1}$ (Control).

The number of compound leaf in tomato was found in range of 17.86 to 21.26. The treatments $\mathrm{T}_{10}$ and $\mathrm{T}_{2}$ were reported to increase the number of compound leaf in tomato by 174.04 and 148.71 percent, respectively over $\mathrm{T}_{1}$ (Control).

The better growth in T10 and T2 might be associated with plant growth promoting activities of combination of Boron, Iron and Zinc on tomato plant which can be confirmed by the finding of Saravaiya et al., (2014) and Dixit et al.,(2018).

\section{Effect of micronutrients on yield} attributing characters

The highest (10.067) number of fruits per plant was recorded in $\mathrm{T}_{10}$ followed by (9.6) in $\mathrm{T}_{8} . \mathrm{T}_{10}$ and $\mathrm{T}_{8}$ were found to increase the number of fruits per plant by 98.15 and 81.10 percent, respectively over $\mathrm{T}_{1}$ (Control). Highest fruit weight was recorded in T10 $(80.83 \mathrm{~g})$ followed by T8 $(76.9 \mathrm{~g})$. Fruit yield was measured in $\mathrm{kg}$ per plot which has been used to determine the estimated yield per hectare. Fruit yield per plot ranged from 3.92 $\mathrm{kg}$ to $7.367 \mathrm{~kg}$ whereas, per hectare from $196 \mathrm{q}$ to $368.33 \mathrm{q}$.

This observation clearly reflects that fruits yield per plot was significantly influenced by combination of micronutrients. The highest $\left(36.83 \mathrm{t} \mathrm{ha}^{-1}\right)$ fruit yield per hectare was in $\mathrm{T}_{10}$ followed by (34.83t ha $\mathrm{ha}^{-1}$ ) in $\mathrm{T}_{2} . \mathrm{T}_{10}$ and $\mathrm{T}_{2}$ were reported to increase the fruits yield by 120.05 and 108.25 percent, respectively over $\mathrm{T}_{1}$ (Control). 
Table.1 Effect of various micronutrients on yield and yield attributing traits of tomato

\begin{tabular}{|c|c|c|c|c|c|c|c|c|c|c|}
\hline Treatments & $\begin{array}{l}\text { Plant } \\
\text { height }\end{array}$ & $\begin{array}{l}\text { No. of } \\
\text { compound } \\
\text { leaf }\end{array}$ & $\begin{array}{l}\text { No. of } \\
\text { cluster }\end{array}$ & $\begin{array}{l}\text { No. of } \\
\text { flowers }\end{array}$ & $\begin{array}{l}\text { Days to } \\
50 \% \\
\text { flowering }\end{array}$ & $\begin{array}{l}\text { No. of } \\
\text { Fruits }\end{array}$ & $\begin{array}{l}\text { Fruit } \\
\text { weight } \\
\text { (gm) }\end{array}$ & $\begin{array}{l}\text { Ascorbic } \\
\text { acid }\end{array}$ & TSS & $\begin{array}{l}\text { yield } \\
\text { (t/ha) }\end{array}$ \\
\hline $\begin{array}{c}\text { T1 } \\
\text { Boron }(0.2 \%)\end{array}$ & 61.47 & 22.80 & 11.73 & 28.40 & 30.67 & 22.27 & 72.22 & 9.71 & 4.60 & 31.05 \\
\hline $\begin{array}{c}\text { T2 } \\
\text { Boron }(0.4 \%)\end{array}$ & 61.80 & 23.60 & 11.20 & 24.40 & 31.67 & 22.60 & 74.34 & 10.50 & 4.30 & 34.83 \\
\hline $\begin{array}{c}\text { T3 } \\
\text { Boron }(0.6 \%)\end{array}$ & 56.27 & 20.60 & 11.47 & 28.73 & 32.67 & 24.07 & 74.72 & 8.37 & 4.43 & 32.55 \\
\hline $\begin{array}{c}\text { T4 } \\
\text { Iron }(0.2 \%)\end{array}$ & 58.67 & 22.80 & 11.60 & 27.47 & 32.00 & 24.20 & 72.77 & 10.44 & 4.50 & 27.41 \\
\hline $\begin{array}{c}\text { T5 } \\
\text { Iron }(0.4 \%)\end{array}$ & 58.07 & 22.07 & 11.33 & 24.40 & 32.33 & 23.73 & 74.00 & 10.58 & 4.46 & 31.60 \\
\hline $\begin{array}{c}\text { T6 } \\
\text { Iron }(0.6 \%)\end{array}$ & 58.53 & 24.13 & 11.47 & 24.07 & 32.33 & 24.07 & 71.49 & 8.55 & 4.30 & 32.05 \\
\hline $\begin{array}{c}\text { T7 - } \\
\text { Zinc }(0.2 \%)\end{array}$ & 60.33 & 23.80 & 11.67 & 23.93 & 30.67 & 23.67 & 69.80 & 10.83 & 4.26 & 29.25 \\
\hline $\begin{array}{c}\text { T8 } \\
\text { Zinc }(0.4 \%)\end{array}$ & 58.47 & 23.07 & 12.73 & 25.67 & 31.67 & 23.40 & 76.91 & 9.73 & 4.43 & 33.95 \\
\hline $\begin{array}{c}\text { T9 } \\
\text { Zinc }(0.6 \%)\end{array}$ & 59.80 & 24.00 & 13.00 & 26.87 & 32.33 & 22.27 & 73.29 & 10.18 & 4.13 & 31.71 \\
\hline $\begin{array}{c}\text { T10 } \\
\mathrm{B}(0.4 \%)+\mathrm{Fe} \\
(0.4 \%)+\mathrm{Zn} \\
(0.4 \%)\end{array}$ & 71.93 & 26.27 & 18.93 & 34.27 & 27.33 & 26.93 & 80.83 & 13.97 & 4.90 & 36.83 \\
\hline T11 Control & 53.80 & 18.73 & 8.93 & 21.07 & 36.00 & 16.60 & 60.78 & 7.44 & 4.36 & 19.60 \\
\hline Mean & 59.92 & 22.90 & 12.19 & 26.30 & 37.80 & 23.07 & 72.83 & 10.02 & 4.42 & 30.96 \\
\hline S.Em \pm & 1.27 & 0.72 & 0.46 & 1.44 & 0.69 & 0.79 & 1.84 & 0.69 & 0.11 & 30.83 \\
\hline C.V. & 3.69 & 5.50 & 5.98 & 9.57 & 3.82 & 5.94 & 4.39 & 11.99 & 4.28 & 11.52 \\
\hline $\begin{array}{l}\text { CD at 5\% } \\
\text { Level }\end{array}$ & 3.79 & 2.16 & 1.25 & 4.30 & 2.07 & 2.35 & 5.48 & 2.07 & 0.33 & 1.25 \\
\hline
\end{tabular}

Average increased yield due to micronutrients application may be attributed to enhanced photosynthesis activity and increased production and accumulation of carbohydrates and favorable effect on vegetative growth and retention of flowers and fruits, which increased number of fruits per plant besides increasing the size. These results are in consonance with the findings of several researchers viz. Bose and Tripathi (1996), Sivaiah et al., (2013), Satya et al., (2013), Bubarai et al., (2017), Haleema et al., (2018) and Reddy et al., (2018).
Effect of micronutrients on quality attributing characters

Total Soluble Solids (TSS) in cucumber fruit was significantly influenced by foliar treatment with micronutrients. The highest (5.7) TSS was found in $T_{9}$ followed by (5.6) in $T_{2}$ and (5.3) in $T_{10} . T_{9}, T_{2}, T_{10}$ had been reported to increase the TSS content by 32.55 , 30.23 and 25.58 percent, respectively over $\mathrm{T}_{1}$ (Control). Ascorbic acid content was found highest (13.97) $\mathrm{T}_{10}$ followed by (10.83) in $\mathrm{T}_{7}$ and (10.58) in $\mathrm{T}_{5}$. The effects of different 
treatments on growth, yield and quality attributes are provided in Table 1.

Foliar application of combination of micronutrient produced maximum fruit yield along with increased quality attributes in tomato. Thus, in present study, foliar spray of T10 B+ Fe+ Zn@ 0.4\% was found much effective over control. It can be concluded that the uptake of micronutrient showed positive results for foliar application of T10 treatment for three times at 30, 45 and 60 days interval after transplanting seedling followed by T2 (B @ 0.4\%).

It was concluded that combination of Boron $(0.4 \%)+$ Iron $0.4 \%)+$ Zinc $(0.4 \%)$ with recommended dose of fertilizer was found effective treatment as compared to other individual treatments resulted in increased yield per plant $(\mathrm{kg})$, number of fruit/plant, number of flower per plant, fruit weight and TSS. Thus, this combination may be suggested for better yield and quality of tomato. Growth, yield as well as quality parameter were to be better in $\mathrm{T} 10$ in comparison to other individual treatments. So it is concluded that "Golden Shiv" variety shows better growth, yield and quality parameters when mixture of Boron $(0.4 \%)+$ Iron $0.4 \%)+$ Zinc $(0.4 \%)$ were applied.

\section{References}

Bubarai, M.L., Tahir, A.M. and Solomon, R.I. 2017. The Micronutrients Boron Its Influence On Growth and Development of Plants and Factors Affecting Availabilty: A Review. J. Agric. Vet. Sci., 10 (12): 10-13.

Bose, U.S, Tripathi S.K. 1996. Effect of micronutrients on growth, yield and quality of tomato cv. Pusa Ruby. Crop. Res., 12 (1): 61-64.

Brown, P. H., Bellaloui, M. A. Wimmer, E. S. Bassil, J. Ruiz, H. Hu, H. Pfeffer, F.
Dannel, and V. Romheld. 2002. Boron in plant biology. Plant Bio., 4: 205-223.

Chand, T.C. and Prasad, V.M. 2017. Effect of micronutrients spray on fruits yield and quality of tomato (Lycopersicon esculentum Mill.). Bull. Env. Pharmacol. Life Sci., 7 (1): 80-87.

Dixit, A., Sharma, D., Sharma, T.S. and Bairwa, P.L. 2018. Effect of foliar application of some macro and micronutrients on growth and yield of tomato (Solanum lycopersicum L.) cv. Arka Rakshak. Int. J. Curr. Microbio. Appl. Sci., 6:197-203.

Dordas, C., Apostolides, G.E. and Goundra, O. 2007. Boron application affects seed yield and seed quality of sugar beets. The J. Agric. Sci., 145: 377-384.

Ejaz, M., Rehman, S.U., Waqas, R., Manan, A., Imran, M. and Bukhari, M.A. 2011. Combined efficacy of macro-nutrients and micro-nutrients as a foliar application on growth and yield of tomato grown by vegetable forcing. Int J. Agro Vet. Medical Sci., 5(3), 327335.

Harlan, J.R. 1992. Crops and Man. 2nd ed. American society of Agronomy, Crop Sciences of America, Madison, WI.

Haleema, B., A. Rab, S.A. Hussain. 2018. Effect of calcium, boron and zinc foliar application on growth and fruit production of tomato. Sarhad J. Agric., 34(1): 19-30.

Kalloo. G. 1985. Tomato. Allied Publishers Private Limited, New Delhi, India. Pp: 204-211.

Khavari-Nejad, R.A., F. Najafi and C. Tofigi, 2009. Diverse responses of tomato to $\mathrm{N}$ and P deficiency. Int. J. Agric. Biol., 11: 209-213.

Naz, R. M. M., Muhammad, S., Hamid, A. and Bibi, F. 2012. Effect of boron on the flowering and fruiting of tomato. Sarhad J. Agric, 28(1): 37-40. 
NHB [National Horticulture Board], Horticultural Statistics at a Glance 2018. Available: http://www.nhb.gov.in

Nonnecke, I.B.L. 1989. Vegetable production. Avi Book publishers. New York, USA. pp. 200- 229.

Reddy, G.P.D, Reddy, P.S.S., Reddy G.C. and Sivaram G.T. 2018. Effect of foliar application of micronutrients on growth and yield parameters in tomato (Solanum lycopersicon L.). Int. J. Pure and Applied Biosci., 6 (2): 929-934.

Saravaiya, S.N., Wakchaure, S.S., Jadhav, P.B., Tekale, G.S.., Patill N.B., Patel, D. J. and Dekhane, S.S. 2014. Effect foliar application of micronutrients on quality. Int. J. Farm Sci., 2(1): 43-46..

Sathya, S., Mahendran, P. P. and Arulmozhiselvan, K. 2013. Influence of soil and foliar application of borax on fractions of boron under tomato cultivation in boron deficient soil of Typic Haplustalf. African J.Agric. Res., 8(21):2567-2571.

Shivapa, M.V. 2005. Effect of micronutrient on growth,yield and quality of tomato (Lycopersicion esculentum Mill) cv.
Pusa Ruby in Hydrabaad conditions thesis submitted to the Acharyan N. G. Ranga Agriculture university in partial fulfillment of the requirement for the award of the degree of master of science in Horticulture department of Horticulture college of Agriculture Acharyan N.

Singh, S., Bairwa1, H., Gurjar, S.C., Kumar, H.R., Jangir, M., and Bagri, U.K. 2018. Effect of foliar spray of micronutrients on uptake of micronutrients in (Solanum esculemntum Mill.) cv. Navoday. Int.J.Curr.Microbiol.App.Sci, 7: 930933.

Sivaiah, N., Swain, S., Raju and Varma, S. 2013. Effect of micronutrients foliar application on seed yield in tomato (Lycopersicon esculentum Mill). International Journal of Plant and Animal Sciences, 1 (7): 70-72.

Stanley, D.W., Bourne, M.C., Stone A.P., Wismer, W.V.1995. Low temperature blanching effects of chemistry, firmness and structure of canned green beans and carrots. Food Sci, 2 (60): 327-333.

\section{How to cite this article:}

Sandeep Kumar, Anamika Verma and Arwankie Shadap. 2019. Yield Improvement in Tomato through Certain Micronutrients in Central Plain Zone (Pb-3) of Punjab, India. Int.J.Curr.Microbiol.App.Sci. 8(05): 1451-1456. doi: https://doi.org/10.20546/ijcmas.2019.805.166 